\title{
Photosynthetic activity in Devonian Foraminifera
}

\author{
Zofia Dubicka $^{1,2}$, Maria Gajewska ${ }^{1}$, Wojciech Kozłowski ${ }^{1}$, Pamela Hallock ${ }^{3}$, and Johann Hohenegger ${ }^{4}$ \\ ${ }^{1}$ Faculty of Geology, University of Warsaw, Warsaw, Poland \\ ${ }^{2}$ Ecological Chemistry, Alfred-Wegener-Institut, Helmholtz-Zentrum für Polar- und Meeresforschung, \\ Bremerhaven, Germany \\ ${ }^{3}$ College of Marine Science, University of South Florida, St Petersburg, Florida, USA \\ ${ }^{4}$ Department of Palaeontology, Universität Wien, Vienna, Austria
}

Correspondence: Maria Gajewska (mi.gajewska@uw.edu.pl)

Received: 27 May 2021 - Discussion started: 3 June 2021

Revised: 19 August 2021 - Accepted: 30 August 2021 - Published: 26 October 2021

\begin{abstract}
Photosynthetically active foraminifera are prolific carbonate producers in warm, sunlit, surface waters of the oceans. Foraminifera have repeatedly developed mixotrophic strategies (i.e., the ability of an organism or holobiont to both feed and photosynthesize) by facultative or obligate endosymbiosis with microalgae or by sequestering plastids (kleptoplasts) of ingested algae. Mixotrophy provides access to essential nutrients (e.g., N, P) through feeding while providing carbohydrates and lipids produced through photosynthesis, resulting in substantial energetic advantage in warm, sunlit environments where food and dissolved nutrients are scarce. Our morphological as well as stable carbon isotope data provide, as of now, the earliest (Mid-Devonian) evidence for photosynthetic activity in the first advanced, multichambered, calcareous foraminifera, Semitextularia, from the tropical shelf of the Laurussia paleocontinent. This adaptation likely influenced the evolutionary radiation of calcareous Foraminifera in the Devonian ("Givetian revolution"), one of the most important evolutionary events in foraminiferal history, that coincided with the worldwide development of diverse calcifying marine communities inhabiting shelf environments linked with Devonian stromatoporoid coral reefs.
\end{abstract}

\section{Introduction}

Among photosynthetically active protists, symbiont-bearing benthic Foraminifera (SBBF) are important carbonate producers (e.g., Prazeres and Renema, 2019, and references therein), contributing nearly $1 \%$ of global calcium carbon- ate budgets (Hohenegger, 2006; Langer et al., 1997). The occurrence of modern SBBF is limited to tropical and warm temperate zones and is related to the light requirements of the hosted symbiotic microalgae (e.g., Hallock, 1979; Larsen and Drooger, 1977; Renema, 2018). Living in warm, shallow, euphotic environments enables hosts to use their tests as "glass houses" suitable for the husbandry of endosymbiotic algae (e.g., Hohenegger, 2009; Hottinger, 1982). Hence, SBBF inhabit mainly upper euphotic shallow-reef and lagoon environments, though some groups hosting diatoms can be found along reef slopes in highly transparent water down to $130 \mathrm{~m}$ depth of the lower euphotic zone (e.g., Hallock, 1999; Hohenegger, 2000). Photosymbioses are energetically and ecologically highly advantageous in warm, clear, nutrient-poor environments (e.g., Hallock, 1981a, 1987; Lee et al., 2010; Schmidt et al., 2004). Through photosynthesis, endosymbionts can provide their hosts with the energy for many of their metabolic needs (i.e., mixotrophy; Dubinsky and Berman-Frank, 2001; Hallock, 1981b; Selosse et al., 2017) while enhancing the process of foraminiferal calcification (e.g., Kinoshita et al., 2017; McConnaughey and Whelan, 1997; ter Kuile, 1991). Benefits for the algal symbionts may include protection afforded by the host tests (Hohenegger, 2000, 2018) if the symbionts actually do benefit (Wooldridge, 2010).

A more direct ecological adaptation that enables foraminifera to be photosynthetically active is by kleptoplasty (Cesbron et al., 2017; Goldstein et al., 2004; Pillet et al., 2011). Foraminifera sequester plastids from microalgal prey, and those plastids can remain photosynthetically active for days to weeks (Jauffrais et al., 2016, 2018). Products 
of photosynthesis, such as glucose, can be especially important during periods of food scarcity. In dysphotic and aphotic habitats like the deeper bathyal benthos, sequestered plastids that originate from planktic diatoms can assimilate inorganic carbon, nitrate, and sulfur (Jauffrais et al., 2019). Feeding upon microalgae and harvesting and maintaining active plastids comprise an evolutionarily more direct way to function as a mixotrophic organism compared to the more complicated array of adaptations associated with obligate symbioses.

Considering the important roles played by SBBF and kleptoplastic foraminifera in the carbonate production of present coral reefs and shallow marine ecosystems (e.g., Baccaert, 1986; Fujita and Fujimura, 2008; Prazeres and Renema, 2019), as well as the advantage of endoplasmic photosynthesis in foraminiferal evolution, we are seeking the first evidence of photosynthetic activity in foraminifera in the past. Presumptive candidates are the first multichambered calcareous foraminifera with leaf-like tests such as Semitextularia (Eifelian-Frasnian), which are morphological counterparts to some recent SBBF, notably peneroplids (Figs. 1, 2). Semitextulariids were globally distributed on Devonian inner shelves, in shallow marine, well-illuminated habitats such as tropical reefs and lagoons (see Table S1). They, as well as other well-known Devonian groups such as Nanicellidae and Eonodosariidae, died out following the Kellwasser event of the Frasnian-Famennian crisis (Vachard et al., 2010) that triggered the rapid collapse of the prolific stromatoporoid coral reef ecosystems. In principle, the origin of Semitextularia occurred at the beginning of the Middle Devonian foraminiferal radiation, which is the so-called "Givetian revolution" (Vachard et al., 2014) and is considered the most important Paleozoic evolutionary event for these protists. This event is associated with "the replacement of the primitive agglutinated wall of the Textulariata by the more advanced secreted wall of the Fusulinata" (Vachard et al., 2014, p. 217; see also BouDagher-Fadel, 2018).

In this paper, we hypothesize that the Devonian semitextularids not only were among the first true multichambered calcareous foraminifera but also may have been the first algal symbiont-bearing or chloroplast-sequestering foraminifera. To test this hypothesis, we compared paleo-populations of Semitextularia derived from facies of coeval horizons (upper Eifelian, Middle Devonian; Skały Beds, Holy Cross Mountains (HCM), central Poland) characterized by contrasting paleodepths with different levels of light intensity representing the tropical southern shelf of the Laurussia paleocontinent (Szulczewski, 1995). Samples were compared in terms of a possible photosynthesis-related microhabitat effect recorded in the stable carbon isotope data from fossil shells, since photosynthesis by algal symbionts in larger modern benthic foraminifera has a significant impact on $\delta^{13} \mathrm{C}$ values. Enrichment of ${ }^{13} \mathrm{C}$ in the microenvironment occurs when ${ }^{12} \mathrm{CO}_{2}$ is preferentially taken up by algae during photosynthesis (Ravelo and Hillaire-Marcel, 2007). Moreover, our findings are supported by ecological similarities and a functional morphological comparison between Semitextularia and recent peneroplids.

\section{Materials and methods}

The studied samples were collected in the lower part of the Skały Formation (upper Eifelian-lower Givetian) outcrop in the Holy Cross Mountains (HCM, central Poland) inlier. The Skały Formation represents an epicratonic facies of the southern (so-called Fennosarmatian) tropical shelf of the Laurussia paleocontinent (Szulczewski, 1995) close to the northern part of the East European Platform (referred to as the Łysogóry unit) located in the HCM. The Skały outcrop $\left(50^{\circ} 53^{\prime} 44.69^{\prime \prime} \mathrm{N}, 21^{\circ} 9^{\prime} 33.75^{\prime \prime} \mathrm{E}\right)$ is part of the well-known Grzegorzowice-Skały (G-S) succession exposed along the Dobruchna brook (Pajchlowa, 1957; Zeuschner, 1869), which is a key section for the Devonian of the Łysogóry facies region (Szulczewski, 1995).

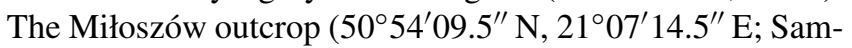
sonowicz, 1936), located $3 \mathrm{~km}$ west of Skały, complements the key succession by virtue of the closely correlated Miłoszów limestone complex (see faunal summary tables in Biernat, 1966; Pajchlowa, 1957; Stasińska, 1958), which was recently exposed in Skały. (For detailed geological, stratigraphic, and sedimentary environment background, see Supplement.)

We examined a total of 25 samples from the upper Eifelian (Middle Devonian) Skały beds of the Holy Cross Mountains in central Poland. The specimens studied were Semitextularia thomasi Miller and Carmer (1933), including the stable isotope data of the tests and the enclosing rock matrix. The latter included (1) a marly intercalation in Miłoszów coral-bearing biostromes (two intervals, Miłoszów 11 and Miłoszów 12), representing an upper euphotic (well-illuminated) environment (10 samples); (2) Skały brachiopod shales (SBSs), containing a mesophotic (lower euphotic) coral assemblage (Skały 11 and $\mathrm{A}+11 \mathrm{~A} / \mathrm{Skały}$ brachiopod shales, 14 samples); and (3) marls with abundant solitary corals (Skały C sample), representing a proximal forereef environment characterized by intermediate photic conditions. All samples were derived from very soft marly clays with low permeability and very low paleoheating rates (Dubicka et al., 2021) that ensured favorable conditions for excellent fossil preservation. Very well preserved three-dimensional specimens, with no sediment or mineral infillings, with original lamellar test microstructure, and with no evidence of any dissolution or recrystallization, were analyzed (Narkiewicz and Malec, 2005). Lack of diagenetic alternation of the Skały samples can be additionally supported by uniquely preserved brachiopods with preserved brachidia, primary shell structures (Biernat, 1966), and in some cases also relicts of the original color pattern (Biernat, 1984). Also, the porous stereom of crinoids includes original 
(metastable) high-Mg calcite, which is the first phase to be affected during the diagenetic alteration of calcareous fossils (Gorzelak et al., 2011).

During maceration, samples were mechanically disintegrated (crumbled into ca. $1-2 \mathrm{~cm}^{3}$ pieces), dried, repeatedly soaked in water and detergent, and then heated and dried again following decantation. To intensify the rock disintegration process, some samples were also subjected to a maceration technique using Rewoquat (Jarochowska et al., 2013). After being washed in an ultrasonic cleaner, the residuum was sieved using a mesh size of $0.053 \mathrm{~mm}$. From the residue, foraminifera were handpicked and studied using a Nikon SMZ18 stereoscopic microscope. More detailed taxonomic observations and photographic documentation were made using a Zeiss Sigma VP scanning electron microscope at the Faculty of Geology, University of Warsaw.

For oxygen and carbon stable isotope analyses, 35 foraminiferal samples and 25 bulk-rock samples were prepared. Foraminifera were manually chosen from the residue prior to undergoing multiple additional cleaning cycles in an ultrasonic cleaner. Sediment-free Semitextularia thomasi specimens were placed in Eppendorf tubes (ca. 10 large adult specimens in each tube). Bulk-rock samples were prepared by grinding a portion of rock material of ca. $2 \mathrm{~g}$ to powder using a mortar. The carbon and oxygen stable isotope analyses were performed at the GeoZentrum at the University of Erlangen, Germany. Samples were reacted with $100 \%$ phosphoric acid at $70^{\circ} \mathrm{C}$ using a GasBench II connected to a Thermo Fisher DELTA V Plus mass spectrometer. Reproducibility of the analyses was $0.06 \%$ and $0.06 \%$ ( $\pm 1 \mathrm{SD}$ ) for $\delta^{18} \mathrm{O}$ and $\delta^{13} \mathrm{C}$ values of laboratory standard Sol $2(n=16)$ and $0.07 \%$ and $0.06 \%$ ( $\pm 1 \mathrm{SD})$ for $\delta^{18} \mathrm{O}$ and $\delta^{13} \mathrm{C}$ values of laboratory standard $\operatorname{Erl} 5(n=22)$, respectively. All carbon and oxygen stable isotope data are reported in per mil relative to the VPDB scale and presented in Tables S1 and S2 for Miłoszów and Skały, respectively.

All statistical analyses were carried out using the program package PAST 4.02 (Hammer et al., 2001).

\section{Results}

\subsection{Morphometrics of the Semitextularia tests}

Semitextularia was the only plurilocular foraminifera in the Skały and Miłoszów assemblages. Semitextularia is the oldest and a a pioneering multichambered form. Apart from Semitextularia, in the studied sections some bilocular and tubular forms of the family Moravamminidae were found, as well as many different microproblematica for which the systematic position and paleoecology are unknown.

The test morphology of Semitextularia specimens from Miłoszów, representing an upper euphotic environment (see Supplement), and Skały, interpreted as a lower euphotic (i.e., mesophotic) environment (Zapalski et al., 2017), was tested for differences in size and shape. Size represented by test height (i.e., maximum diameter) did not differ significantly among samples (ANOVA; $p\left(H_{0}\right)=0.499$; Tables S2, S3), following pairwise comparisons. Only specimens from Skały 1 were, on average, slightly smaller compared to the other samples. Shape, represented by the parameters $\sqrt{\text { area }} /$ height and width/height, also did not differ among samples (ANOVA; $p\left(H_{0}\right)=0.697, p\left(H_{0}\right)=0.122$; Table S4), again with some smaller width/height ratios for Skały 1. The complete overlapping of samples is supported by regression functions of test area to test height (Fig. 3).

\section{$3.2 \delta^{13} \mathrm{C}$ and $\delta^{18} \mathrm{O}$ values in Devonian foraminiferal shells along with rock-matrix samples}

Stable carbon isotope data from Semitextularia specimens, as well as from bulk-rock samples, were compared (Tables S5, S6). For Semitextularia, $\delta^{13} \mathrm{C}$ values were significantly higher in specimens from Miłoszów $(2.86 \%$, $2.71 \%$ ) compared to Skały $\left(1.47 \%\right.$, $0.84 \% o, 1.60 \%$; $p\left(H_{0}\right)=1.05 \times$ $\left.10^{-6}\right)$. In contrast, in bulk-rock samples, $\delta^{13} \mathrm{C}$ values were significantly lower in Miłoszów $(-0.05 \%$ o, $-2.24 \%$ ) compared to Skały $11(1.71 \%$ ) and Skały C $(0.96 \%$ o specimens, with intermediate values in Skały $\mathrm{A}+11 \mathrm{~A}$ rock samples $\left(0.10 ; p\left(H_{0}\right)=3.07 \times 10^{-11}\right)$.

Stable oxygen isotope values in Semitextularia tests also resulted in significant differences among samples $\left(p\left(H_{0}\right)=3.56 \times 10^{-8}\right)$. Averaged $\delta^{18} \mathrm{O}$ values were significantly lower in Miłoszów $(-6.35 \%$, $-6.44 \%$ ) compared to Skały C (-5.68\%o) and Skały A + 11A (-5.49\%o), while Skały 11 values fell in between $(-5.95 \%$ ). Values for $\delta^{18} \mathrm{O}$ of bulk-rock samples also differed significantly $\left(p\left(H_{0}\right)=9.44 \times 10^{-8}\right)$, with Miłoszów samples showing significantly lower values $(-6.62 \%$ o, $-6.91 \%$ ) compared to Skały $11(-5.56 \%$ ) and Skały C (-5.43\%o) samples and values for Skały $\mathrm{A}+11 \mathrm{~A}$ samples falling in between $(-6.17 \%$ ).

Comparisons among stable isotope values of Semitextularia specimens and bulk-rock samples differed (Table S7). In Miłoszów 11 samples, the $\delta^{13} \mathrm{C}$ values in Semitextularia $(2.86 \%$ ) were much higher than for the bulk-rock sample $(-0.05 \%$ ). Similar differences were found at Miłoszów 12, with high values for Semitextularia $(2.71 \%$ ) compared to the bulk-rock sample $(-0.05 \%$ ). Skały samples are quite different from those of Miłoszów. In material from both Skały 11 and Skały $\mathrm{A}+11 \mathrm{~A}$, the $\delta^{13} \mathrm{C}$ values of bulk-rock samples were significantly higher (both samples $1.71 \%$ ) compared to those of Semitextularia (1.47\%o in Skały $11,0.84 \%$ in Skały A + 11A). At Skały C, however, the stable carbon isotope values were statistically similar: $1.60 \%$ for Semitextularia versus $0.96 \%$ o for bulk rock.

Comparing stable oxygen isotope data between Semitextularia and bulk-rock samples produced different results. The $\delta^{18} \mathrm{O}$ values do not differ between Semitextularia specimens and bulk rock in either Miłoszów sample (Table S7). 
Similar congruence was found in Skały C samples, with $\delta^{18} \mathrm{O}$ values of $-5.68 \%$ for Semitextularia specimens and $-5.43 \%$ o for bulk rock. Although stable oxygen isotope values for Skały $11(-5.95 \%$ o for Semitextularia, $-5.56 \%$ o for bulk rock) were similar, because the variance in both groups was extremely low $(0.003,0.005)$, the differences were significant. In contrast, the $\delta^{18} \mathrm{O}$ values of Semitextularia specimens $(-5.49 \%$ ) and bulk-rock samples $(0.10 \%$ ) from Skały A $+11 \mathrm{~A}$ were very different.

Comparisons of $\delta^{13} \mathrm{C}$ and $\delta^{18} \mathrm{O}$ values based on foraminifera and bulk-rock samples are shown as scatter diagrams for the Miłoszów and Skały samples (Fig. 4).

\section{Discussion}

A simplified depositional biofacies model for the uppermost Eifelian Skały Formation in the Łysogóry basin (HCM) is provided in Fig. 5; our interpretation of the paleoenvironments represented by Semitextularia-bearing samples is indicated. The ${ }^{13} \mathrm{C}$ enrichment of Semitextularia foraminiferal tests compared to the associated bulk rock (matrix) was interpreted as related to the fractionation of isotopes due to photosynthetic activity in foraminifera that either hosted photosynthetic endosymbionts or were kleptoplastic.

The hypothesis of there being photosynthetic activity in Semitextularia is based on many previous observations that intracellular photosynthesis influences the $\delta^{13} \mathrm{C}$ of foraminiferal tests (e.g., Ravelo and Fairbanks, 1995; Wefer et al., 1981; Wefer and Berger, 1991). Fractionation of carbon isotopes during photosynthesis can produce $\delta^{13} \mathrm{C}$ differences between foraminiferal tests and the $\delta^{13} \mathrm{C}_{\mathrm{DIC}}$ of the ambient seawater in which the foraminifera live, as it strongly influences the foraminiferal microenvironment (i.e., the "internal carbon pool") (e.g., Ravelo and Hillaire-Marcel, 2007; Wefer and Berger, 1991; Zeebe et al., 1999). The probability that Semitextularia was photosynthetically active is supported by the apparently optically transparent test structure (Fig. $1 \mathrm{~h}-\mathrm{j}$ ) that enabled light penetration (Dubicka et al., 2021). Furthermore, the test morphology of Semitextularia is comparable to representatives of some smaller SBBF to the point that Semitextularia seems to be the fossil morphological counterpart of peneroplids. Specimens in both taxa can be characterized by fan-like, bilaterally flat tests with high surfaceto-volume ratios (Hohenegger, 2009) and multiple apertures forming a series of small holes along the entire last chamber. This kind of test represents a way to increase the surface area, allowing more symbionts/plastids to be positioned just beneath the test wall to gather light (e.g., Haynes, 1965; Hansen and Buchhardt, 1979), while multiple apertures are morphological adaptations to resist hydrodynamic forces by strengthening attachments through bundles of pseudopodia, as exemplified by the Peneroplis life strategy (Hohenegger, 2011). Specifically, peneroplids hide in the uppermost layer of sand grains or attach to algal filaments with a net of pseudopods (Fig. 2b; Hohenegger, 2009, 2011).

However, differences in $\delta^{13} \mathrm{C}$ values in Semitextularia compared to the bulk-rock samples are much smaller in Skały A11 + A samples than those recorded in specimens from Miłoszów and are very minimal in Skały 11 and Skały C specimens. Therefore, there is no clear evidence for photosynthetic activity in the Semitextularia tests from the Skały settings, which likely were characterized by lower light intensities (Zapalski et al., 2017). The paleodepth of Skały is estimated as ca. 30-40 m (see Supplement), which is within the range of the water depth of Holocene mixotrophic foraminifera, primarily those housing diatoms, which did not evolve until the Jurassic (Sims et al., 2006). Species hosting dinoflagellates, chlorophytes, or rhodophytes tend to be shallower dwelling, especially in shelf-margin environments with reduced water transparency such as the Florida reef tract (Baker et al., 2009) compared to in much clearer oceanic waters (Hohenegger, 2006). Thus, reduced photosynthetic activity at the seafloor at the Skały location was likely related to the input of nutrients and fine sediments into the basin, thereby limiting light penetration required for sufficient photosynthetic activity to influence carbon isotopic ratios in the foraminiferal tests (e.g., Hansen and Buchhardt, 1979). Light penetration declines exponentially with water depth and so declines rapidly with depth even with relatively small changes in water transparency (e.g., Hallock and Schlager, 1986; Hohenegger, 2000, 2004).

Another point to discuss is the consistency in test morphology of the studied Semitextularia as shown by regression analyses of the test width/test height and $\sqrt{\text { area }} /$ test height ratios (Fig. 3). These ratios can indicate light requirements when harboring microalgae (Hohenegger, 2004), as has been observed in the surface / volume ratios of algal symbiontbearing rotaliids and porcelanous species whose distributions are well correlated with depth (e.g., Eder et al., 2018; Hallock, 1979; Hohenegger, 2000). Because light intensities would have been higher in the upper euphotic Miłoszów location compared to the mesophotic Skały sites, one could expect differences in test parameters. For example, in hyaline amphisteginid species, which are characterized by a highly transparent lamellar test structure, the maximum test diameters are relatively consistent within their depth range, though their minimum diameters (also referred to as "test thickness") decline with depth (e.g., Hallock and Hansen, 1979; Hohenegger et al., 1999; Larsen and Drooger, 1977). In Amphistegina, optimal light penetration into the test is facilitated by changes in lamellar thickness, which could not be demonstrated for Semitextularia because it possesses nonlamellar walls like miliolid foraminifera (e.g., peneroplids). However, the micro-erosion of the test surface of the specimen shown in Fig. 1a, as well as irregularities in chamber walls shown in a thin section (Fig. 1h1), indicates at least partial internal subdivision of the individual chambers, analogous to that seen in modern Archaias angulatus (e.g., Cottey and Hallock, 1988). 

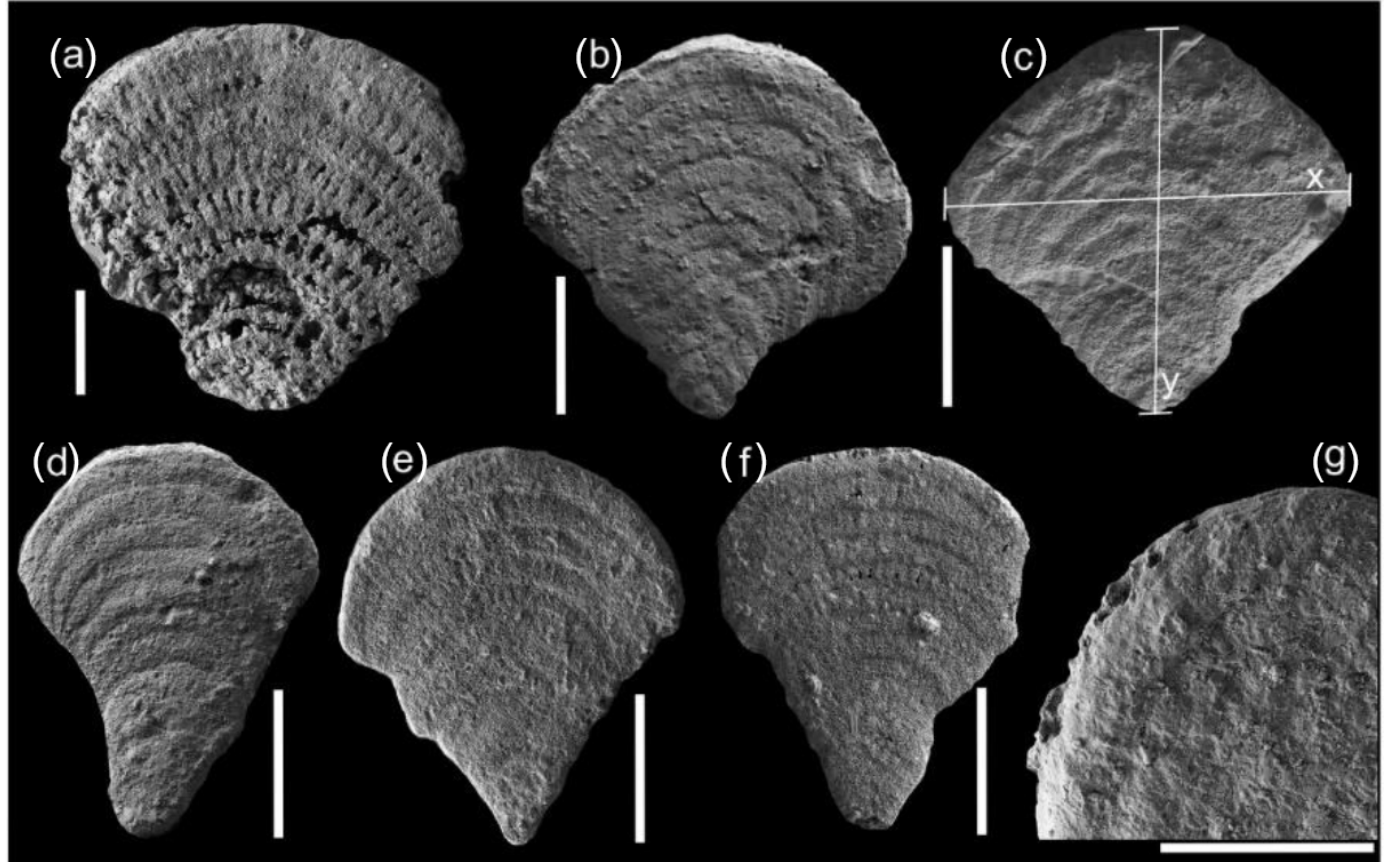

(g)
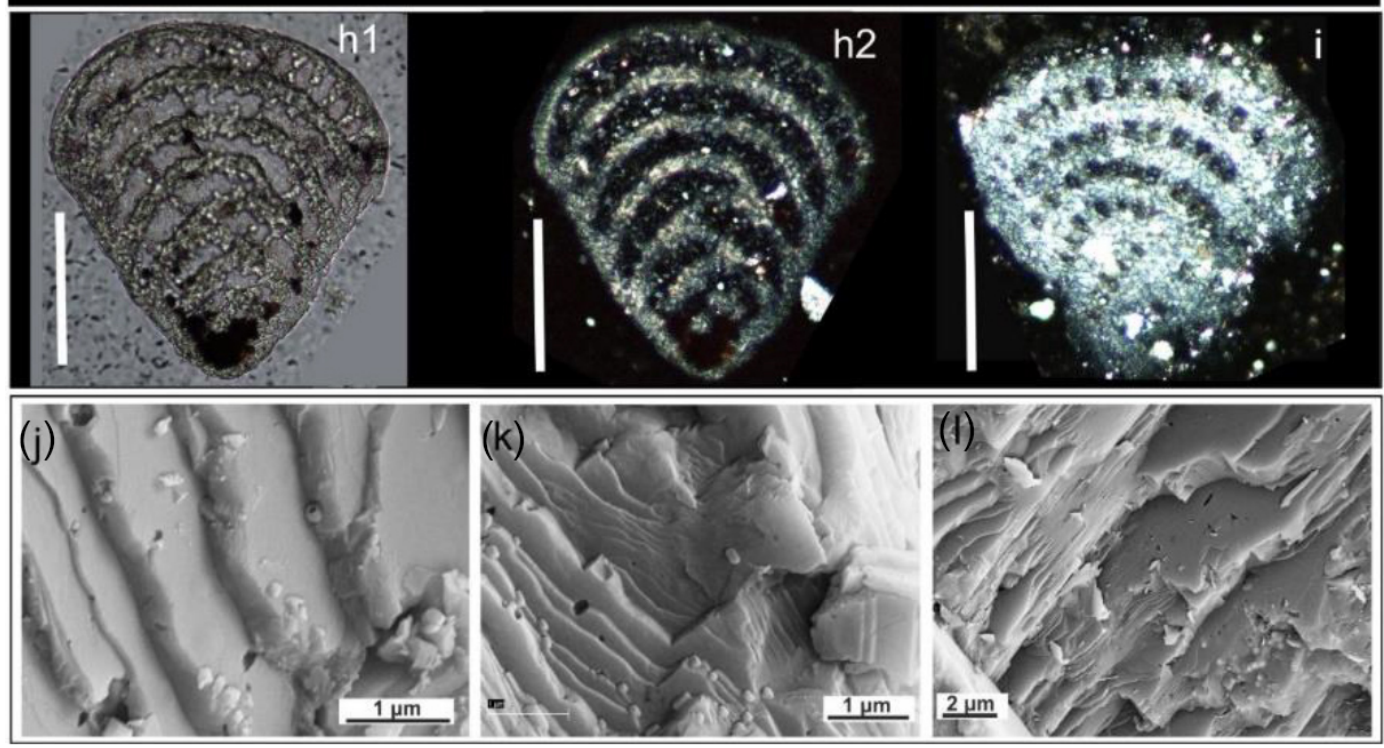

Figure 1. Images of Semitextularia Miller and Carmer (1933) specimens: (a-g) SEM images of the Semitextularia tests; (h) internal test texture in a conventional-light microscope image (h1) and using polarized-light microscopy (h2); (i) image of Semitextularia thin section showing transparent test (a-i; scale bars are equal to $100 \mu \mathrm{m})$; (j-l) SEM images showing foliated structure of the test wall. (a) Miłoszów, sample B1, MWGUW ZI/67/MG7.02. (b) Miłoszów, sample 11, MWGUW ZI/67/MG5.03. (c) Miłoszów, sample 11, MWGUW ZI/67/MG5.04. (d) Miłoszów, sample 12, MWGUW ZI/67/MG5.30. (h) Miłoszów, sample 12, MWGUW ZI/67/MG5.27. (i) Miłoszów, sample MO, MWGUW ZI/67/MG5.40. (j) Miłoszów, sample 12R, MWGUW ZI/67/MG9.23. In panel (c), $x$ indicates test height (i.e., maximum diameter) while $y$ is test width.

If Semitextularia was photosynthetically active, at least in quite shallow water, the following question arises: were these foraminifera kleptoplastic, as seen in some modern taxa (Jauffrais et al., 2016, 2018), or were they indeed symbiotic with some kind of microalgae? And if Semitextularia were photosymbiotic, was the relationship a facultative symbiosis or an obligate symbiosis? And in the latter case, were the algal cells essentially organelles, as with peneroplids in which the red algal cells are not bound by a host membrane (e.g., Lee and Anderson, 1991, and references therein)? These questions cannot be answered with our current specimens and stable carbon isotope data. Photosynthetic activity suf- 

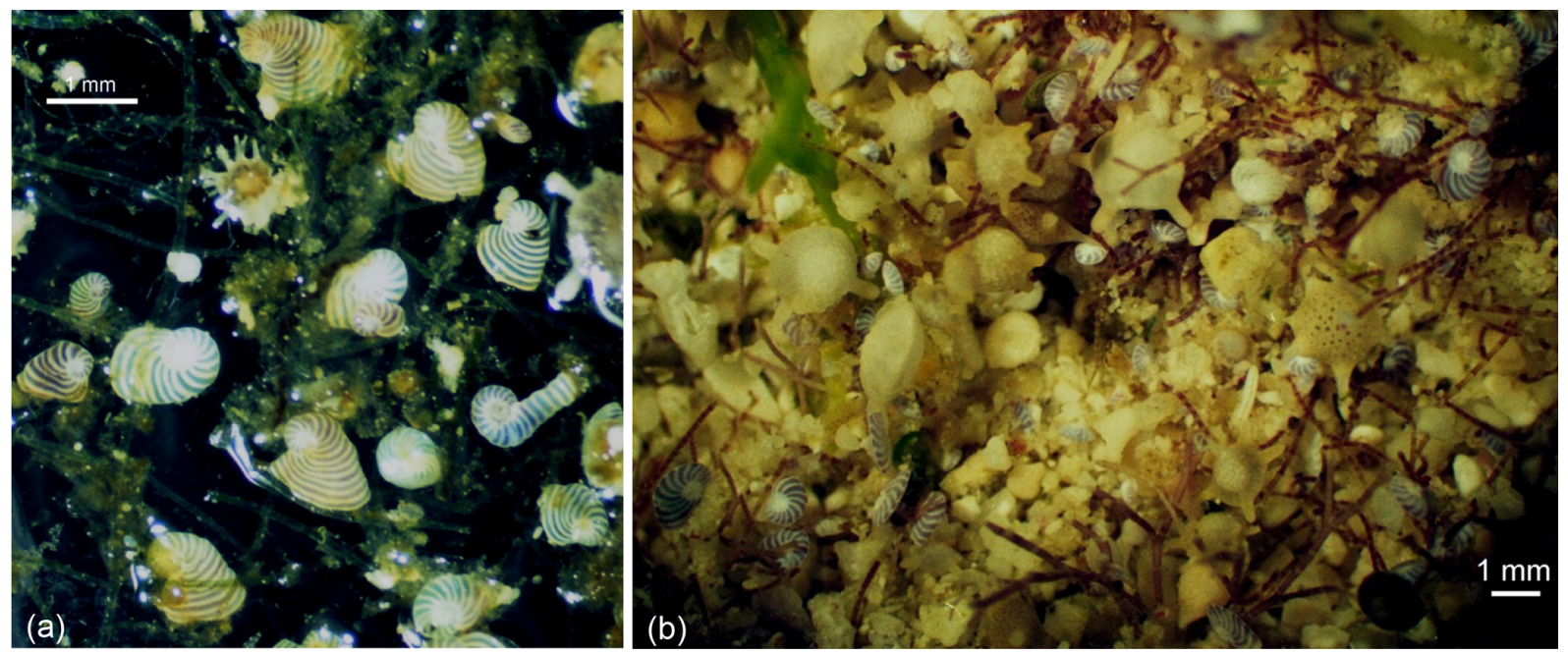

Figure 2. (a) Living peneroplids and Neorotalia calcar from algal mats on reef crests in Belau. (b) Peneroplis planatus attached to filamentous microalgae within sand grains from the reef crest at Sesoko Island, Japan, together with Calcarina gaudichaudii and Baculogypsina sphaerulata.

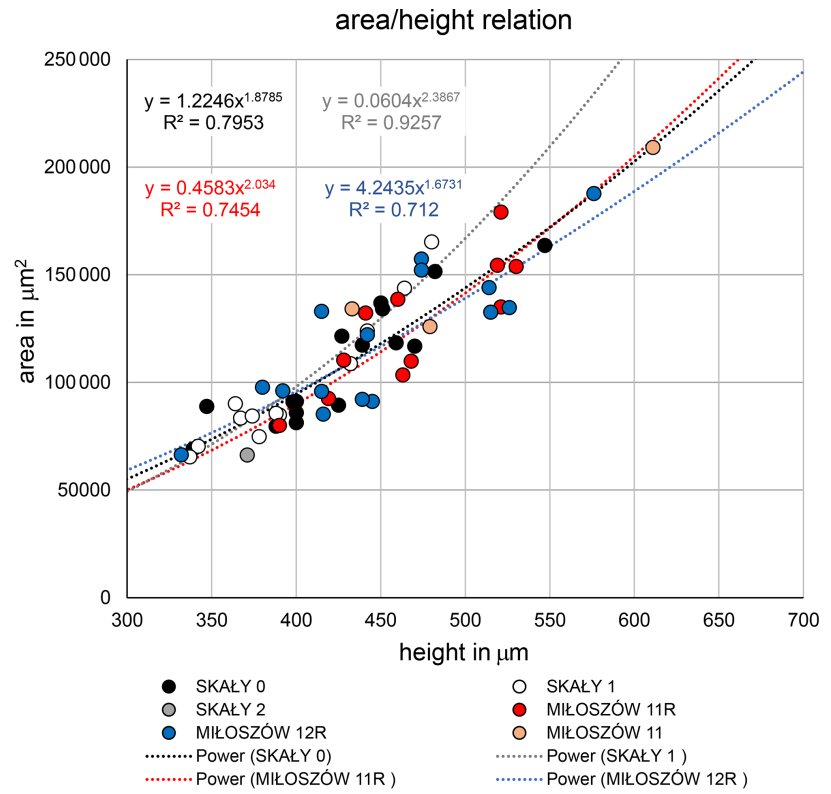

Figure 3. Relationships between test area and test height fitted by power functions.

ficient to influence stable carbon isotope ratios declines with depth in foraminifera with diatom endosymbionts (Hansen and Buchhardt, 1979). Moreover, obligate endosymbiosis is a more complex co-evolutionary process, especially obligate photosymbioses in which the host is unable to survive without symbionts. Facultative algal symbioses, which occur in some planktic taxa, are unknown among Holocene SBBF (e.g., Hallock, 1999; Lee and Anderson, 1991; Prazeres and Renema, 2019). Because photosymbiosis in benthic foraminifera may have been somewhat unstable at the

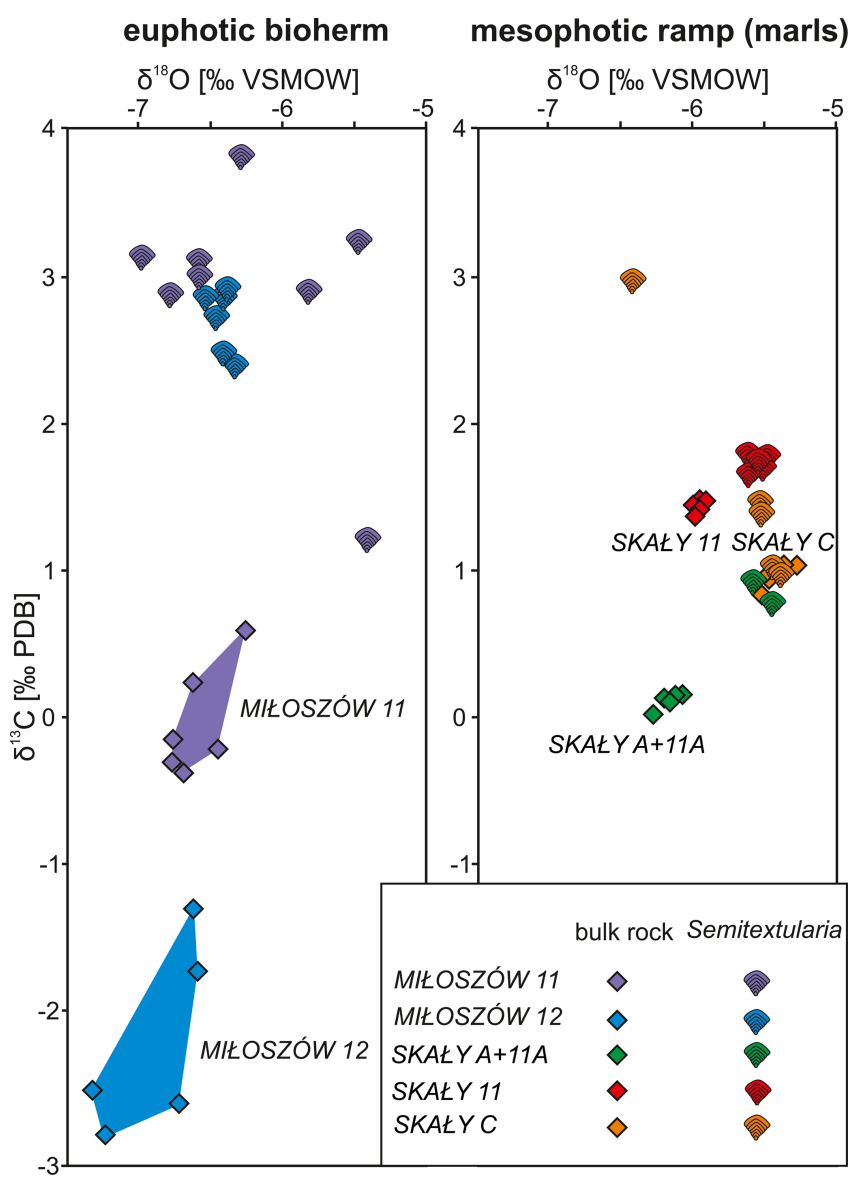

Figure 4. Variations in $\delta^{13} \mathrm{C}$ and $\delta^{18} \mathrm{O}$ values of Semitextularia tests and bulk-rock samples from Miłoszów and Skały. 


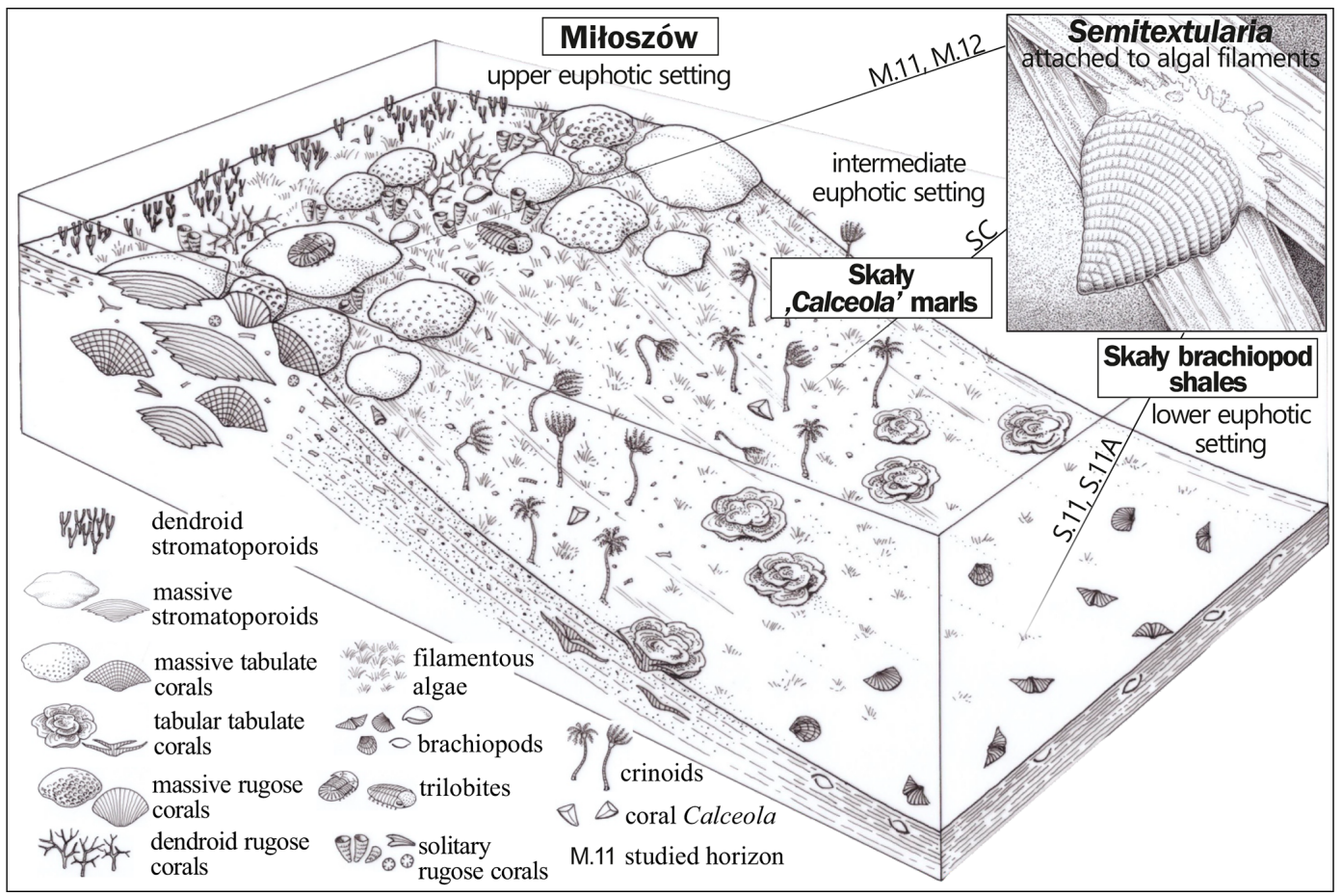

Figure 5. Simplified depositional biofacies model for the uppermost Eifelian Skały Formation in the Łysogóry basin (HCM), with general locations indicated for Semitextularia-bearing samples.

beginning, benefitting from mixotrophy by sequestering and maintaining chloroplasts from their algal food is a much simpler adaptation and therefore a parsimonious hypothesis. Evidence for photosynthetic activity, whether kleptoplastic or symbiotic, is supported by our stable carbon isotope data, specifically by the differences in stable isotope values between foraminiferal tests and bulk-rock samples, which appear to have been related to the paleodepth/illumination intensity.

The basic life history strategy of the Foraminifera involves alternation of generations (Goldstein, 1997) and can be assumed for Semitextularia based on both phylogeny and possible trimorphism in fossilized tests. For example, the initial chambers of the specimen in Fig. 1e appear to be smaller than those of other specimens shown, possibly indicating a sexually produced agamont (microsphere, B form). Diameters of initial chambers in specimens in Fig. $1 b, d$, and $\mathrm{f}$ are nearly double that of the specimen in Fig. 1e, while the diameter of initial chambers of the specimen in Fig. 1c is about 3 times larger. The specimen shown in Fig. 1a is poorly preserved but does resemble that of Fig. 1c. These differences are similar to the size range demonstrated for Amphistegina gibbosa by Harney et al. (1998) for agamonts (microspheric, sexually produced, B form), megalospheric specimens produced by megalospheric parents (schizonts, A1 forms), and megalospheric specimens that produced gametes (gamonts, A2 form). As hypothesized by Dettmering et al. (1998) and Krüger et al. (1996), the transfer of endosymbionts during sexual reproduction is certainly more complicated than direct transfer during asexual reproduction. Thus, having successive asexual generations (schizogony) as a key strategy for local population increase while sexual reproduction facilitates dispersal is highly advantageous in foraminiferal taxa that host algal endosymbionts (e.g., Hallock and Seddighi, 2021; Pappazoni and Seddighi, 2018). Future studies that examine initial chamber-size distributions in fossil populations of Semitextularia or other suspected photosymbiotic taxa could provide additional evidence for symbiosis rather than kleptoplasty.

The evolution of foraminiferal lineages characterized by algal endosymbiosis has occurred repeatedly and independently numerous times since the late Paleozoic, involving unrelated algal groups as well. Previously, the earliest calcareous foraminifera postulated to host algal endosymbionts were the large, complex fusulinids (e.g., BouDagher-Fadel, 2018, and references therein). A true symbiotic relationship between Semitextularia and an algal taxon cannot be ruled out from the observations reported here. Nevertheless, our observations are also consistent with kleptoplasty, which is a simpler hypothesis to explain photosynthetic activity in Semitextularia. 


\section{Conclusions}

Semitextularia, an extinct and pioneering multichambered calcareous foraminiferal genus (Eifelian, Middle Devonian), shows morphological homology and a comparable habitat with recent photosymbiont-bearing peneroplids. The $\delta^{13} \mathrm{C}$ enrichment, up to $2.86 \%$ in relation to rock-matrix samples, indicates that Semitextularia utilized photosynthetic activity, either through kleptoplasty by acquiring and maintaining plastids from microalgal food or by maintaining algal endosymbionts, which would have involved co-evolution with a microalgal taxon. This beneficial ecological behavior could have had an impact on the evolutionary radiation of calcareous multichambered Foraminifera during the Mid-Devonian radiation of carbonate-producing biotas.

Data availability. All data are included in the article or Supplement.

Supplement. The supplement related to this article is available online at: https://doi.org/10.5194/bg-18-5719-2021-supplement.

Author contributions. ZD developed the original idea presented in the paper. $\mathrm{ZD}$ and $\mathrm{WK}$ designed research. MG performed foraminiferal extraction and prepared samples for isotopic studies. $\mathrm{ZD}, \mathrm{MG}$, and WK carried out fieldwork. ZD, MG, WK, and JH prepared figures; JH provided statistical analyses. All authors analyzed data and contributed to writing the paper.

Competing interests. The contact author has declared that neither they nor their co-authors have any competing interests.

Disclaimer. Publisher's note: Copernicus Publications remains neutral with regard to jurisdictional claims in published maps and institutional affiliations.

Acknowledgements. Zofia Dubicka thanks the Alexander von Humboldt Foundation for supporting her research stay at the Alfred Wegener Institute.

Financial support. This research has been supported by the Narodowe Centrum Nauki (grant no. 2018/29/B/ST10/01811).

Review statement. This paper was edited by Steven Bouillon and reviewed by Marcelle BouDagher-Fadel and Antonino Briguglio.

\section{References}

Baccaert, J.: Foraminiferal bio- and thanatocoenoses of reef flats, Lizard Island, Great Barrier Reef, Australia, Nature of Substrate, Ann. Soc. Roy. Zool. Bel., 116, 3-14, 1986.

Baker, R. D., Hallock, P., Moses, F. E., Williams, D. E., and Ramirez, A.: Larger foraminifers of the Florida Reef Tract, USA: Distribution patterns on reef-rubble habitats, J. Foramin. Res., 39, 267-277, 2009.

Biernat, G.: Middle Devonian brachiopods from the Bodzentyn Syncline (Holy Cross Mountains, Poland), Acta Palaeontol. Pol., 17, 1-162, 1966.

Biernat, G.: Colour pattern in Middle Devonian rhynchonellid brachiopods from the Holy Cross Mountains, Acta Geol. Pol., 34, 63-72, 1984.

BouDagher-Fadel, M. K.: Evolution and Geological Significance of Larger Benthic Foraminifera, 2nd Edn., UCL Press, London, 704 pp., 2018.

Cesbron, E., Geslin, C., Le Kieffre, T., and Jauffrais, T.: Sequestered chloroplasts in the benthic foraminifer Haynesina germanica: Cellular organization, oxygen fluxes and potential ecological implications, J. Foramin. Res., 47, 268-278, 2017.

Cottey, T. L. and Hallock, P.: Test surface degradation in Archaias angulatus, J. Foramin. Res., 18, 187-202, 1988.

Dettmering, C., Röttger, R., Hohenegger, J., and Schmaljohann, R.: The trimorphic life cycle in foraminifera: Observations from cultures allow new evaluation, Eur. J. Protistol., 34, 363-368, 1998.

Dubicka, Z., Gajewska, M., Kozłowski, W., and Mikhalevich, V.: Test structure in some pioneer multichambered Paleozoic Foraminifera, P. Natl. Acad. Sci. USA, 118, 1-6, 2021.

Dubinsky, Z. and Berman-Frank, I.: Uncoupling primary production from population growth in photosynthesizing organisms in aquatic ecosystems, Aquat. Sci., 63, 4-17, 2001.

Eder, W., Hohenegger, J., and Briguglio, A.: Test flattening in the larger foraminifer Heterostegina depressa: Predicting bathymetry from axial sections, Paleobiology, 44, 76-88, 2018.

Fujita, K. and Fujimura, H.: Organic and inorganic carbon production by algal symbiont-bearing foraminifera on northwest Pacific coral-reef flats, J. Foramin. Res., 38, 117-126, 2008.

Goldstein, S. T.: Gametogenesis and the antiquity of reproductive pattern in the Foraminiferida, J. Foramin. Res., 27, 319-328, 1997.

Goldstein, S. T., Bernhard, J. M., and Richardson, E. A.: Chloroplast sequestration in the foraminifer Haynesina germanica: Application of high pressure freezing and freeze substitution, Microsc. Microanal., 10, 1458-1459, 2004.

Gorzelak, P., Stolarski, J., Dubois, P., Kopp, C., and Meibom, A.: ${ }^{26} \mathrm{Mg}$ labeling of the sea urchin regenerating spine: Insights into echinoderm biomineralization process, J. Struct. Biol., 176, 119126, 2011.

Hallock, P.: Trends in test shape in large, symbiont-bearing foraminifera, J. Foramin. Res., 9, 61-69, 1979.

Hallock, P.: Light dependence in Amphistegina, J. Foramin. Res., 11, 40-46, 1981a.

Hallock, P.: Algal symbiosis: a mathematical analysis, Mar. Biol., 6, 249-255, 1981b.

Hallock, P.: Fluctuations in the trophic resource continuum: a factor in global diversity cycles?, Paleoceanography, 2, 457-471, 1987. 
Hallock, P.: Symbiont-bearing foraminifera, in: Modern Foraminifera, edited by: Sen Gupta, B. K., Springer, 12339, 1999.

Hallock, P. and Hansen, H. J.: Depth adaptation in Amphistegina: Change in lamellar thickness, Bull. Geol. Soc. Den., 27, 99-104, 1979.

Hallock, P. and Schlager, W.: Nutrient excess and the demise of coral reefs and carbonate platforms, Palaios, 1, 389-398, 1986.

Hallock, P., and Seddighi, M.: Why did some larger benthic foraminifera become so large and flat?, Sedimentology, 12837, 1-14, https://doi.org/10.1111/sed.12837, 2021.

Hammer, Ø., Harper, D., and Paul, D. R.: Past: Paleontological Statistics Software Package for Education and Data Analysis, Palaeontol. Electron., 4, 1-9, 2001.

Hansen, H. J. and Buchhardt, B.: Depth distribution of Amphistegina in the Gulf of Elat, Utrecht Micropaleontol. Bull., 30, 205244, 1979.

Harney, J., Hallock, P., and Talge, H.K.: Observations on a trimorphic life cycle in Amphistegina gibbosa populations from the Florida Keys, J. Foramin. Res., 28, 141-147, 1998.

Haynes, J.: Symbiosis, wall structure and habitat in foraminifera, Contrib. Cushman Found. Foramin. Res., 16, 40-44, 1965.

Hohenegger, J.: Coenoclines of larger foraminifera, Micropaleontology, 46, 127-151, 2000.

Hohenegger, J.: Depth coenoclines and environmental considerations of western Pacific larger foraminifera, J. Foramin. Res., 34, 9-34, 2004.

Hohenegger, J.: The importance of symbiont-bearing benthic foraminifera for West Pacific carbonate beach environments, Mar. Micropaleontol., 61, 4-39, 2006.

Hohenegger, J.: Functional shell geometry of symbiont-bearing benthic foraminifera, Galaxea JCRS, 11, 81-89, 2009.

Hohenegger, J.: Large Foraminifera: Greenhouse constructions and gardeners in the oceanic microcosm, The Kagoshima University Museum, Kagoshima, Japan, 2011.

Hohenegger, J.: Foraminiferal growth and test development, EarthSci. Rev., 185, 140-162, 2018.

Hohenegger, J., Yordanova, E., Nakano, Y., and Tatzreiter, F.: Habitats of larger foraminifera on the upper reef slope of Sesoko Island, Okinawa, Japan, Mar. Micropaleontol., 36, 109-168, 1999.

Hottinger, L.: Larger Foraminifera, giant cells with a historical background, Naturwissenschaften, 69, 361-371, 1982.

Jarochowska, E., Tonarová, P., Munnecke, A., Ferrová, L., Sklenář, J., and Vodrážková, S.: An acid-free method of microfossil extraction from clay-rich lithologies using the surfactant Rewoquat, Palaeontol. Electron., 16, 1-16, 2013.

Jauffrais, T., Jesus, B., Metzger, E., Mouget, J.-L., Jorissen, F., and Geslin, E.: Effect of light on photosynthetic efficiency of sequestered chloroplasts in intertidal benthic foraminifera (Haynesina germanica and Ammonia tepida), Biogeosciences, 13, 2715-2726, https://doi.org/10.5194/bg-13-2715-2016, 2016.

Jauffrais, T., LeKieffre, C., Koho, K. A., Tsuchiya, M., Schweizer, M., Bernhard, J. M., Meibom, A., and Geslin, E.: Ultrastructure and distribution of kleptoplasts in benthic foraminifera from shallow-water (photic) habitats, Mar. Micropaleontol., 138, 4662, 2018.

Jauffrais, T., LeKieffre, C., Schweizer, M., Geslin, E., Metzger, E., Bernhard, J. M., Jesus, B., Filipsson, H. L., Maire, O., and Meibom, A.: Kleptoplastidic benthic foraminifera from aphotic habi- tats: Insights into assimilation of inorganic $\mathrm{C}, \mathrm{N}$ and $\mathrm{S}$ studied with sub-cellular resolution, Environ. Microbiol., 21, 125-141, 2019.

Kinoshita, S., Eder, W., Wo, J., Hohenegger, J., and Briguglio, A.: Growth, chamber building rate and reproduction time of Palaeonummulites venosus (Foraminifera) under natural conditions, Coral Reefs, 36, 1097-1109, 2017.

Krüger, R. Röttger, R. Lietz, R., and Hohenegger, J.: Biology and reproductive process of the large foraminiferan Cycloclypeus carpenteri (Protozoa, Nummulitidae), Arch. Protist Stud., 147, 307 321, 1996.

Langer, M. R., Silk, M. T., and Lipps, J. H.: Global ocean carbonate and carbon dioxide production: the role of reef foraminifera, J. Foramin. Res., 27, 271-277, 1997.

Larsen, A. R. and Drooger, C. W.: Relative thickness of the test in the Amphistegina species of the Gulf of Elat, Utrecht Micropal. Bull., 15, 225-240, 1977.

Lee, J. J. and Anderson, O. R.: Symbiosis in Foraminifera, in: Biology of Foraminifera, edited by: Lee, J. J. and Anderson, O. R., LA Press, London, 157-220, 1991.

Lee, J. J., Cervasco, M., Morales, J., Billik, M., and Fine, M.: Symbiosis drove cellular evolution: Symbiosis fueled evolution of lineages of Foraminifera (eukaryotic cells) into exceptionally complex giant protists, Symbiosis, 51, 13-25, 2010.

McConnaughey, T. A. and Whelan, J. F.: Calcification generates protons for nutrient and bicarbonate uptake, Earth-Sci. Rev., 42 95-117, 1997.

Miller, A. K. and Carmer, A. M.: Devonian Foraminifera from Iowa, J. Paleontol., 7, 423-431, 1933.

Narkiewicz, K. and Malec, J.: New conodont CAI database (CAI), Przegląd Geologiczny, 53, 33-37, 2005 (in Polish).

Pajchlowa, M.: Dewon w profilu Grzegorzowice-Skały (in Polish with English summary), Biuletyn Instytutu Geologicznego, 122, 145-254, 1957.

Papazzoni, C. A. and Seddighi, M.: What, if anything, is a Nummulite Bank?, J. Foramin. Res., 48, 276-287, 2018.

Pillet, L., de Vargas, C., and Pawlowski, J.: Molecular identification of sequestered diatom chloroplasts and kleptoplastidy in foraminifera, Protist, 162, 394-404, 2011.

Prazeres, M. and Renema, W.: Evolutionary significance of the microbial assemblages of large benthic foraminifera, Biol. Rev., 94, 828-848, 2019.

Ravelo, A. C. and Fairbanks, R. G.: Carbon isotopic fractionation in multiple species of planktonic foraminifera from core-tops in the tropical Atlantic, J. Foramin. Res., 25, 53-74, 1995.

Ravelo, A. C. and Hillaire-Marcel, C.: The use of oxygen and carbon isotopes of Foraminifera in paleoceanography, in: Proxies in Late Cenozoic Paleoceanography, edited by: Hillaire-Marcel, C., and De Vernal, A., Elsevier Science, 735-764, 2007.

Renema, W.: Terrestrial influence as a key driver of spatial variability in large benthic foraminiferal assemblage composition in the central Indo-Pacific, Earth-Sci. Rev., 177, 514-544, 2018.

Samsonowicz, J.: Sprawozdanie z badań w r, 1935 na północ od kopalni Staszic między Pokrzywianką, Psarką i Swiśliną (in Polish), Posiedzenie naukowe Państwowego Instytutu Geologicznego, 44, 41-45, 1936.

Schmidt, D. N., Renaud, S., Bollmann, J., Schiebel, R., and Thierstein, H. R.: Size distribution of Holocene planktic foraminifer 
assemblages: Biogeography, ecology and adaption, Mar. Micropaleontol., 50, 319-338, 2004.

Selosse, M. A., Charpin, A., and Not, F.: Mixotrophy everywhere on land and in water. The grand écart hypothesis, Ecol. Lett., 20, 246-263, 2017.

Sims, P. A., Mann, D. G., and Medlin, L. K.: Evolution of the diatoms: Insights from fossil, biological and molecular data, Phycologia, 45, 361-402, 2006.

Stasińska, A.: Tabulata. Heliolitida et Chaetetida du Devonien moyen des monts de Sainte-Croix, Acta Palaeontol. Pol., 3, 161282, 1958.

Szulczewski, M.: Depositional evolution of the Holy Cross Mts. (Poland) in the Devonian and Carboniferous - a review, Geol. Q., 39, 471-488, 1995.

ter Kuile, B.: Mechanisms for calcification and carbon cycling in algal symbiont-bearing foraminifera, in: Biology of Foraminifera, edited by: Lee, J. J. and Anderson, O. R., London Academic Press, London, UK, 73-89, 1991.

Vachard, D., Haig, D. W, and Mory, A. J.: Lower Carboniferous (middle Visean) foraminifers and algae from an interior sea, Southern Carnarvon Basin, Australia, Geobios, 47, 57-74, 2014.
Vachard, D., Pille, L., and Gaillot, J.: Palaeozoic Foraminifera: Systematics, palaeoecology and responses to global changes, Rev. de Micropaleontol., 53, 209-254, 2010.

Wefer, G. and Berger, W. H.: Isotope paleontology: growth and composition of extant calcareous species, Mar. Geol., 100, 207248, 1991.

Wefer, G., Killingley, J. S., and Lutze, G. F.: Stable isotopes in recent larger foraminifera, Palaeogeogr. Palaeocl., 33, 253-270, 1981.

Wooldridge, S. A.: Is the coral-algae symbiosis really "mutually beneficial" for the partners?, Bioessays, 32, 615-625, 2010.

Zapalski, M. K., Wrzołek, T., Skompski, S., and Berkowski, B.: Deep in shadows, deep in time: The oldest mesophotic coral ecosystems from the Devonian of the Holy Cross Mountains (Poland), Coral Reefs, 36, 847-860, 2017.

Zeebe, R. E., Bijma, J., and Wolf-Gladrow, D. A.: A diffusionreaction model of carbon isotope fractionation in foraminifera, Mar. Chem., 64, 199-227, 1999.

Zeuschner, L.: Geognostische Beschreibung der mittleren devonischen Schichten zwischen Grzegorzowice und Skaly-Zagaje bei Nowa Slupia, Z. Deut. Geolog. G., 21, 263-274, 1869. 